\title{
Oyster Mushroom Cultivation - A Budding Enterprise for Self Employment of Rural Youth and Farm Women in Tinsukia District of Assam
}

\author{
Sarodee Boruah ${ }^{1 *}$, Sanjoy Borthakur ${ }^{1}$ and M. $\operatorname{Neog}^{2}$ \\ ${ }^{1}$ Krishi Vigyan Kendra, Tinsukia, ${ }^{2}$ Directorate of Extension Education, Assam Agricultural \\ University, Jorhat, Assam, India \\ *Corresponding author
}

\section{A B S T R A C T}

\section{Keywords}

Oyster mushroom, Nutritional security, Diversified agriculture, Front line demonstration

Article Info

Accepted:

12 December 2020 Available Online: 10 January 2021
During recent times, much importance has been given on cultivation of nutri rich crops so that we can meet the demand of nutritional security of India's ever increasing population. In this context, diversified agricultural system is very much needed which includes activities mushroom cultivation as well. Mushroom farming today is being practiced in more than 100 countries and its production is increasing at an annual rate of 67\%. In Assam, amongst all the edible mushrooms, especially cultivation of oyster mushroom has increased tremendously because of their abilities to grow at a wide range of temperature and utilizing various agro-based residues and easy availability of the raw materials. Keeping these points in view, Krishi Vigyan Kendra Tinsukia, Assam has conducted Front Line Demonstration (FLD) programmes among farmers, rural youth and farm women of 10 numbers of villages to make them aware about the scope of mushroom farming in employment generation. Under the demonstration programmes, the crop of oyster mushroom was harvested in four flushes; the highest yield of about $145 \mathrm{~kg}$ was recorded in the month of January followed by $138 \mathrm{~kg}$ in the month of February. The lowest yield of $110 \mathrm{~kg}$ was recorded in the month of April. The economic analysis of oyster mushroom production revealed that farmers were able to get highest net income of Rs. $17,600.00$ in the year 2019-20 with B:C ratio of 2.42. From these results we can say that the oyster mushroom cultivation is a profitable venture for self employment of rural youth as well as for farm women.

\section{Introduction}

Agriculture has remained the mainstay of Indian economy. Presently, Indian Agriculture is witnessing a phase of diversification. During recent times, much importance has been given on cultivation of nutri-rich crops so that we can meet the demand of nutritional security of India's ever increasing population. In this context, diversified agricultural system is very much needed which includes activities such as mushroom cultivation, vermicompost cultivation, food processing, fishery, dairy etc. Amongst these, mushroom cultivation is one of the important to meet the demand of 
nutritional security and health and environmental sustainability (Singh et al., 2017).

Mushroom, the conspicuous umbrella-shaped fruiting body (sporophore) of certain fungi is typically of the order Agaricales of the phylum Basidiomycota. In a restricted sense, mushrooms are edible fungi. Use of mushrooms as food and therapeutic have been known since long time, as it is evident from the descriptions in old epics Vedas and Bible. Mushroom contains about 20-35\% of protein (dry weight) (Kalac, 2009). In addition to protein, mushroom is an excellent source of vitamin $\mathrm{D}$, minerals such as potassium, iron, copper, zinc and manganese, amino acids especially rich in lysine and glutamic acid, high fibre content, low in calories, fat free, cholesterol free, gluten free and very low in sodium (Sharma et al., 2017).

Edible mushrooms are of different types viz., Oyster, White button, Milky and Paddy straw. Oyster mushroom belonging to the genus Pleurotus is an edible mushroom having excellent flavor and taste (Shah et al., 2004) and most popular mushroom in India as well as in Assam. Oyster mushrooms are native to North eastern United States. It has also been found to be ideal for people suffering from anaemia, hyperacidity, and constipation.

Mushroom farming today is being practiced in more than 100 countries and its production is increasing at an annual rate of $6-7 \%$ (Huchchannanavar et al., 2020). It is very much advantageous as because it can be grown even by landless farmers, that too on waste material and could be a good source of protein (Ambili and Nitiya, 2014).

From 2010- 2017, the mushroom industry in India has registered an average growth rate of $4.3 \%$ per annum. Out of the total mushroom produced, white button mushroom share is
$73 \%$ followed by oyster mushroom (16\%), paddy straw mushroom $(7 \%)$ and milky mushroom (3\%) (Sharma et al., 2017).

In Assam, amongst all the edible mushrooms, cultivation of oyster mushroom has increased tremendously because of their abilities to grow at a wide range of temperature and utilizing various agro-based residues and easy availability of the raw materials. In Assam especially in the Tinsukia district popularity of mushroom cultivation and consumption is increasing but there is still need of more awareness about the health benefits as well as employment opportunities of this high valued crop. Especially there is gap in market linkage, processing and entrepreneurship development by mushroom farming.

The climate of Tinsukia district is very much congenial for cultivation of Oyster mushroom which can be cultivated more or less round the year. Almost 58\% people of Tinsukia district belong to small and marginal farmers. Their income level is quite low for a sustained livelihood. In order to raise their farming income, mushroom cultivation was considered to be an alternative source of income. Keeping these points in view, Krishi Vigyan Kendra (KVK), Tinsukia has conducted front line demonstration programmes among the farmers including rural youth and farm women of 10 numbers of villages to make them aware about the scope of mushroom farming in employment generation especially for rural youth and farm women.

\section{Materials and Methods}

Frontline demonstration on oyster mushroom cultivation was conducted in 10 selected villages viz., Raidung Balugarah, Dighal Haku, Disawjaan, Gutibari, Hukani village Lungkashi, Bordirak, Baruahula, Ubon Kakopathar, Panitola, Denka village of 
Tinsukia district of Assam consecutively for last 3 years (2017-18, 2018-19 and 2019-20) covering 95 farmers, 100 farm women and 55 rural youths. Under Front Line Demonstrations, unemployed rural youth, farmers and farm women were given quality mushroom spawn and polythene bags to cultivate oyster mushroom.

During the programme each and every step of the technology of oyster mushroom cultivation has been demonstrated practically. Besides, different capacity building activities including training, farmer's scientist's interaction on various aspects of mushroom cultivation.

To assess the economic viability of the technology net profit and the cost benefit ratio has been calculated based on the demonstrations conducted among the farmers of 10 villages. Extension literatures were also distributed among the participating farmers.

\section{Details of the technology}

\section{Raw materials used}

The three major raw materials used in the process of cultivation of oyster mushroom are rice straw as a substrate, spwan and polythene bags of size $40 \mathrm{~cm} \times 60 \mathrm{~cm}$ for spwaning.

Besides these some of the other materials such as chaff cutter, drum, aluminium sauce pan etc are needed for chopping, soaking and boiling of rice straw. Hand sprayer is required for watering of the mushroom beds just after completion of the mycelia growth.

\section{Process of cultivation}

\section{Preparation of substrate}

For cultivation of oyster mushroom rice straw is the best substrate. First rice straw is cut into small pieces of 1 inch size and soaked in cold water for overnight.

\section{Hot water treatment}

Wet straw is boiled at around $80-90^{\circ} \mathrm{C}$ for at least 1 hour. The hot water treatment is done for sterilization of the substrate.

\section{Drying of rice straw}

The boiled straw is sun dried in a clean cemented floor. Drying is the crucial point of the mushroom cultivation process as because excess moisture in the straw may inhibit mycelial run of oyster mushroom.

\section{Spawning}

Polythene bags of size of $40 \mathrm{~cm} \times 60 \mathrm{~cm}$ are used for oyster mushroom spawning. Before spawning, 20-25 numbers of holes are made around the polythene bag with the help of a puncher.

The bottom of the bag is tied with a thread to give a cylindrical shape to the bed. Spawn at the rate of $80 \mathrm{gm}$ per bed is used. The bag is filled with alternate layers of straw and spawn. There will be 4 layers of spawn and 5 layers of straw in a $5 \mathrm{~kg}$ capacity bag. After spawning the bag is tied with the help of a thread and incubated in a dark room for spwan run. The spwan run is completed in 1520 days.

\section{Pinning}

The pinhead appears in 6-8 days after completion of spwan run. Just after pinhead formation a mist of water is sprayed every day over the beds. Mushrooms were harvested before the cap is fully opened. From one $5 \mathrm{~kg}$ capacity bag we can harvest $2-2.5 \mathrm{~kg}$ mushroom. 


\section{Oyster mushroom production flowchart}

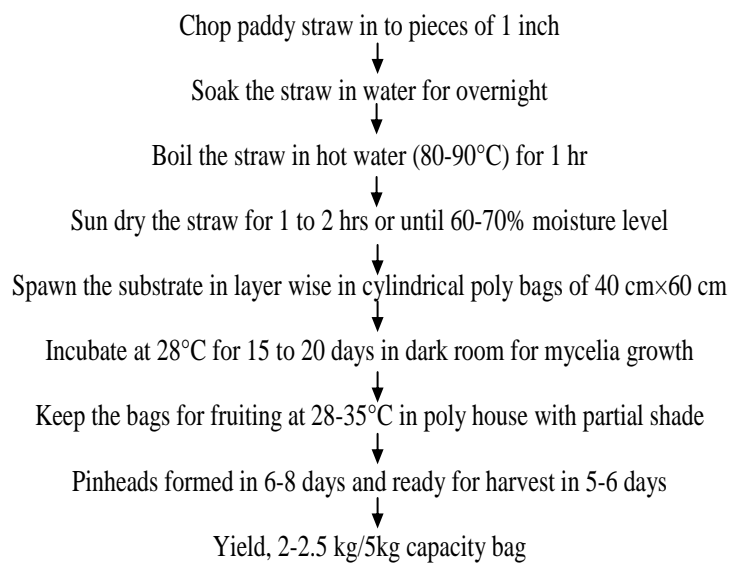

\section{Results and Discussion}

In the recent years mushroom cultivation is gaining popularity among rural people of Assam especially in Tinsukia district. In this regard, KVK, Tinsukia is playing a major role in providing trainings, awareness camps and demonstration programmes at different parts of the Tinsukia district during last three years. KVK, Tinsukia has conducted a number of front line demonstrations among 250 numbers of farmers of Tinsukia district in 2017 to 2020. One extension bulletin was also prepared to create awareness about production and consumption of oyster mushroom. Mushroom cultivation is an agribusiness which creates lot of employment and income generation opportunities especially for weaker sections of the society (Singh et al., 2015). Cultivation technology of oyster mushroom is very simple and a very low cost technology which does not require costly infrastructure facilities. Even landless farmers can also go for mushroom cultivation. Oyster mushroom can be grown in Assam throughout the year. Varieties such as Pleurotus florida, $P$. sapidus, $P$. sajor caju, $P$. djamor and $P$. ostreatus etc. can be grown in winter season from the month of September-October to March-April. Some of the varieties such as $P$. citrinopileatus can be grown in summer season also. It takes nearly about 35-40 days to complete the process of mushroom cultivation. Under this front line demonstration programme, from each bag the mushroom was harvested and weighed periodically. First harvesting was done in the month of December and the subsequent harvestings in the succeeding months up to the month of April (Table 1). The crop of oyster mushroom was harvested in four flushes, the highest yield was recorded in the month of January of about $145 \mathrm{~kg}$ followed by $138 \mathrm{~kg}$ in the month of February (Table 1). The lowest yield of $110 \mathrm{~kg}$ was recorded in the month of April (Table 1). Similar results were also recorded by Chitra and his co workers in the year 2018. They recorded highest yield of $26.08 \mathrm{~kg}$ in the month of January and lowest yield of $15.10 \mathrm{~kg}$ in the month of April. This reduced yield might be due to the high temperature $\left(37^{\circ} \mathrm{C}\right.$ to $\left.40^{\circ} \mathrm{C}\right)$ in the month of April and low relative humidity resulted in low yield (Chitra et al., 2018). The overall yield improvement was recorded in first and second seeding in the month of January and February as mentioned due to optimum temperature and relative humidity for the development of mycelium, which helped in improving the yield of the crop (Chitra et al., 2018). 
Table.1 Yield of oyster mushroom of consecutive three years

\begin{tabular}{|l|c|c|c|c|}
\hline \multirow{2}{*}{ Parameters } & \multicolumn{2}{|c|}{ Mushroom yield (Kg /Unit) } & \multicolumn{2}{c|}{$\begin{array}{c}\text { Month wise } \\
\text { Average (Kg/Unit) }\end{array}$} \\
\cline { 2 - 4 } December & $\mathbf{2 0 1 7 - 1 8}$ & $\mathbf{2 0 1 8 - 1 9}$ & $\mathbf{2 0 1 9 - 2 0}$ & 128.0 \\
\hline January & 110.0 & 120.0 & 155.0 & 145.0 \\
\hline February & 125.0 & 135.0 & 175.0 & 138.3 \\
\hline March & 125.0 & 135.0 & 155.0 & 130.0 \\
\hline April & 120.0 & 130.0 & 140.0 & 110.0 \\
\hline Total & 100.0 & 105.0 & 125.0 & \\
\hline $\begin{array}{l}\text { Yearly Average yield } \\
\text { (Kg/ Unit*) }\end{array}$ & 600.0 & 625.0 & 750.0 & \\
\hline
\end{tabular}

*One unit consist of 50 numbers of beds

Table. 2 Economic analysis of mushroom production of consecutive three years

\begin{tabular}{|l|c|c|c|}
\hline Parameters & $\mathbf{2 0 1 7 - 1 8}$ & $\mathbf{2 0 1 8 - 1 9}$ & $\mathbf{2 0 1 9 - 2 0}$ \\
\hline Average yield per month (kg/Unit) & 120.0 & 125.0 & 150.0 \\
\hline Gross cost (Rs./Unit*) & $10,800.00$ & $11,000.00$ & $12,400.00$ \\
\hline Gross income (Rs./Unit) & $24,000.00$ & $25,000.00$ & $30,000.00$ \\
\hline Net income (Rs./Unit) & $13,500.00$ & $15,000.00$ & $17,600.00$ \\
\hline B: C ratio & 2.22 & 2.27 & 2.42 \\
\hline
\end{tabular}

*One unit consist of 50 numbers of beds

Fig.1 Introduction of the technology during 2017-2020 through FLD programme

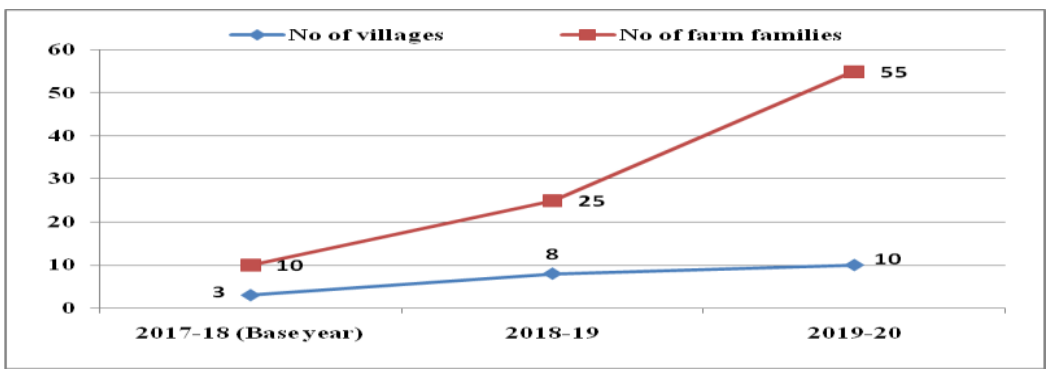

Fig.2 Horizontal spread of the technology during 2018-2020

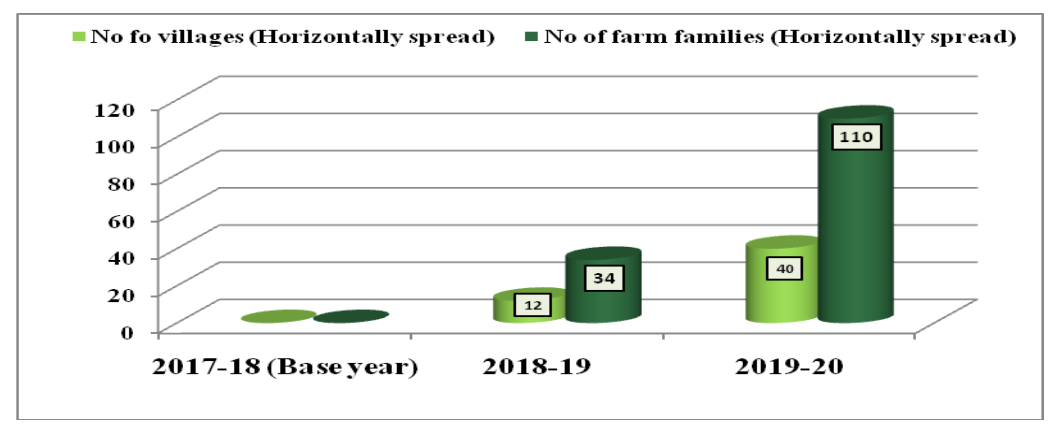


The economic analysis of oyster mushroom production revealed that the cost of production of mushroom is Rs. 10,800.00, $11,000.00$ and $12,400.00$ in the year of 2017 18, 2018-19 and 2019-20, respectively. Results showed that the highest gross income of Rs. 30,000.00 was recorded in the year 2019-2020 followed by Rs. 25,000.00 and Rs. 24,000.00 in the year 2018-19 and 2017-18 respectively (Table 2). Similarly, Singh and his co workers (2018) reported economic viability of the mushroom production as the mushroom yield ranged from 80 to 120 $\mathrm{kg} / 100 \mathrm{~kg}$ wheat straw and total income from $100 \mathrm{~kg}$ wheat straw ranged from Rs. 640012000 with net profit of Rs. 4650-12000 in six months. Farmers could able to earn net income ranging from Rs. 13500.00 to Rs. $17,600.00$ with $\mathrm{B}: \mathrm{C}$ ratio of 2.22 to 2.42 from oyster mushroom cultivation (Table 2). Considering the results obtained and feasibility of the cultivation in the state of Assam, we can say that the oyster mushroom cultivation is a profitable venture for upliftment of rural income.

Initially, KVK, Tinsukia has introduced this technology in 3 numbers of villages involving 10 numbers of farm families in the year 2017 18 , later on in $2018-19$, it was introduced in 8 villages (25 farm families) and in 10 villages (55 farm families) during 2019-20 (Fig 1). Record also has been taken on horizontal spread of the technology during these three years and results showed that the technology has been horizontally spread to 12 villages and 34 farm families in 2018-19 and 40 villages and 110 farm families (2019-20) (Fig 2).

Kapoor and Behl (1983) and Chauhan and Sood (1992) also reported that mushroom growing has been appreciated as a technically feasible and profitable venture and widely accepted by the researchers as a good venture to uplift income, employment generation and rural development. It was also reported that mushroom production for economic empowerment of farm women is a profitable activity. Women can easily go for mushroom cultivation since it doesn't require hard labour. There is also a scope to increase the net income by producing the major input i.e. the quality spawns for their own. That is why the urgent need of the hour is to develop spawn production units within the district.

In conclusion the oyster mushrooms are known to many farmers and but cultivation was limited. After introduction from KVK Tinsukia, in recent times, this sector is growing in a very faster rate. For better self life the value addition of oyster mushroom is need to be done. Awareness programmes and demonstrations on value addition and processing of mushroom has already been started by KVK Tinsukia and playing a major role in dissemination of improved technologies of mushroom cultivation among farmers, rural youth and farm women in the form of awareness programmes, training and demonstrations. The regular supply of quality spawn is the single most important interventions in Tinsukia district that needs to be addressed for mushroom entrepreneurship to flourish. To overcome this problem there is a need of at least one mushroom spawn production unit in each block. Then only there will be continuous production of mushroom which ultimately will lead to quality food supply and employment generation. In conclusion we can say that mushroom production can boost economic condition of rural youth and rural women and thereby can help to improve the rural economy of the district as a whole.

\section{Acknowledgement}

We acknowledged the help, guidance and continuous support received from Dr. P. K. Pathak, Director of Extension Education, 
Assam Agricultural University, Joraht-13, Assam and Dr. A. K. Tripathi, Director ATARI, Zone VI, Guwahati, Assam.

\section{References}

Ambili, S., and Nithya, T. P. 2014. Oyster mushroom cultivation- A study in Palakkad district, Kerela. Int. J. Management. Soc. Sci. Res. Rev. 1: 104-105.

Chauhan, S.K., and Sood, R. P. 1992. Economic of production and marketing of mushroom in Kangra district, Himachal Pradesh. Indian J. Agriculture Marketing. 6(2): 44- 49.

Chitra, K. R., Venkatesh, K., Dhanalakshmi, P.T., Sharavanan, C., BaliSasikumar and Karthikeyani Vijayakumari, K. 2018. Production and Economic Analysis of Oyster Mushroom (Pleurotus florida). Int. J. Curr. Microbiol. App. Sci. 7(09): 379-383.

Kalac, P. 2009. Chemical composition and nutritional value of European species of wild growing mushrooms: A review. Food chem. 113(1): 9-16.

Kapoor, P., and Behl, N. 1983. Cultivation of button mushroom - Gram Prodyogiaka.
3(2): 101.

Shah, Z.A., Ashraf, M. and Ishtiaq, M. 2004. Comparative study on cultivation and yield performance of oyster mushroom (Pleurotus ostreatus) on different substrates (wheat straw, leaves, saw dust). Pak. J. Nutri. 3 (3): 158-160.

Sharma, V. P., Annepu, S. K., Gautam, Y., Singh, M., and Kamal, S. 2017. Status of mushroom production in India. Mushr. Res. 26 (2), 111-120.

Shilpa H., Ravishankar, G., and Anandkumar, V. 2020. Impact of Milky Mushroom Cultivation and Value Addition Trainings among the Unemployed Youth of Ballari District. Int. J. Curr. Microbiol. App. Sci. 9(1): 1853-1860.

Singh, B. D., Verma, M., Kumar, R., Gupta, P. C. and Aditya., 2018. Economic Empowerment of Rural Farm Women through Mushroom Production - A Case Study of Patna District, India. Int. J. Curr. Microbiol. App. Sci. 7(5): 348351.

Singh, R. and Suresh, R. 2007. Cost-benefit analysis of mushroom cultivation. Indian J. Agric. Res. 41(4): 256-261.

\section{How to cite this article:}

Sarodee Boruah, Sanjoy Borthakur and Neog, M. 2021. Oyster Mushroom Cultivation - A Budding Enterprise for Self Employment of Rural Youth and Farm Women in Tinsukia District of Assam. Int.J.Curr.Microbiol.App.Sci. 10(01): 2155-2161.

doi: https://doi.org/10.20546/ijcmas.2021.1001.247 